\title{
ANÁLISE CRÍTICA ACERCA DA POSSIBILIDADE DE APLICAÇÃO DA JUSTIÇA RESTAURATIVA PELO MINISTÉRIO PÚBLICO DO TRABALHO
}

\author{
CRITICAL ANALYSIS OF THE POSSIBILITY \\ OF APPLYING RESTORATIVE JUSTICE BY \\ THE LABOR PROSECUTION OFFICE
}

\author{
SANDOVAL ALVES DA SILVA ${ }^{1}$ \\ CAMILLE DE AZEVEDO ALVES ${ }^{2}$ \\ JOÁO RENATO RODRIGUES SIQUEIRA ${ }^{3}$
}

\section{RESUMO}

O presente trabalho objetiva estudar a possibilidade de aplicação da justiça restaurativa na tutela coletiva extrajudicial pelo Ministério Público do Trabalho em irregularidades trabalhistas noticiadas à instituição. Adotou-se como método de abordagem o hipotético-dedutivo e, como método de procedimento, a pesquisa bibliográfica. Verificou-se que o Ministério Público é uma instituição com poderes para formular argumentos no intuito de deliberar e de discutir, em igualdade de condições, com os interessados e os envolvidos em conflitos, problemas e insatisfações sociais. Conclui-se que o Ministério Público do Trabalho é um ator

1 Doutor e mestre em Direito pela Universidade Federal do Pará (UFPA), na linha de pesquisa sobre constitucionalismo, democracia e direitos humanos, Procurador do trabalho lotado na Procuradoria Regional do Trabalho da 8. ${ }^{2}$ Região, Professor da Universidade Federal do Pará (UFPA), na Pós-Graduação de Direito - PPGD com as disciplinas "Solução de problemas e de conflitos por acordo e a concretização dos direitos sociais" e "Processo dialógico de concretização dos direitos sociais", bem como na graduação com as disciplinas Teoria Geral do Processo e Processo Civil. Líder do Grupo de Pesquisa "Comunidade, conflitos, problemas, insatisfações sociais e o estudo sobre paz" (CNPq). Membro do IIDP (Instituto Ibero Americano de Direito Processual). Associado da ANNEP (Associação Norte Nordeste dos Professores de Processo), ex-Coordenador Nacional da Coordenadoria Nacional de Promoção de Igualdade de Oportunidades e Eliminação da Discriminação no Trabalho - COORDIGUALDADE, ex-professor de Direito Financeiro e Orçamento Público, ex-procurador do Estado do Pará, ex-assessor da Auditoria Geral do Estado do Pará e ex-analista de controle externo do Tribunal de Contas do Estado do Pará. https://orcid.org/0000-0002-1795-2281. http://lattes.cnpq.br/2744878887909140. sandovalsilva4@yahoo.com.br.

2 Graduanda em Direito pela Universidade Federal do Pará. Bolsista de Extensão no Projeto "A aplicação das práticas restaurativas no Núcleo de Prática Jurídica da Universidade Federal do Pará como um processo acadêmico da extensão universitária" (2019-2020). Voluntária no Projeto de Extensão Capacitação de acesso à justiça no Projeto Escrevendo e Reescrevendo a Nossa Historia (PERNOH)(2019-atual). Bolsista PIBIC/UFPA (2017-2018). Membro do Grupo de Pesquisa "Tradição da Lei Natural" (CNPq) e do Grupo de Pesquisa "Comunidade, conflitos, problemas, insatisfações sociais e o estudo sobre paz" (CNPq). https://orcid.org/0000-0002-2879-088X. http://lattes.cnpq.br/3381321326552718. camilledeazevedoalves@ gmail.com.

3 Graduando em Direito-UFPA; bolsista de iniciação científica PIBIC 2019-2020; voluntário PIBEX 2019-2020; Membro do grupo de Pesquisa "Tradição da Lei Natural" (CNPq) e do Grupo de Pesquisa "Comunidade, conflitos, problemas, insatisfações sociais e o estudo sobre paz" (CNPq). https://orcid.org/0000-0002-5411-7322. http://lattes.cnpq.br/0696701101651511. joao.renato.rs@gmail.com.

Como citar esse artigo/How to cite this article:

SILVA, Sandoval Alves da. ALVES, Camille de Azevedo. SIQUEIRA, João Renato Rodrigues. Análise crítica acerca da possibilidade de aplicação da justiça restaurativa pelo ministério público do trabalho. Revista Meritum, Belo Horizonte, vol. 15, n. 1, p. $280-$ 301, jan./abr. 2020. DOI: https://doi.org/10.46560/meritum.v15i1.7916 
político-burocrático com poderes para instaurar procedimentos dialógicos para proceder à concretização de direitos sociais, à harmonização e à pacificação social, sendo as práticas restaurativas uma das possibilidades de atuação nos procedimentos ministeriais.

PALAVRAS-CHAVE: Justiça restaurativa. Direitos Sociais. Tutela Coletiva Extrajudicial. Ministério Público do Trabalho.

\section{ABSTRACT}

The current work seeks to study the possibility of applying restorative justice to extrajudicial collective protection by the Labor Prosecution Office in labor irregularities reported to the institution. The hypothetical-deductive approach was adopted and the bibliographic research was herein employed. It was found that the Prosecution Office is an institution with power to develop arguments in order to deliberate and discuss on equal terms with those interested in and the ones involved in conflicts, problems and social dissatisfactions. It concludes that the Labor Prosecution Office is a political-bureaucratic actor with power to establish dialogical procedures of accomplishment of social rights, harmonization and social pacification, with restorative practices being possible performances in ministerial procedures.

KEYWORDS: Restorative Justice.Social Rights. out of court collective relief . Labor Prosecution Office.

\section{INTRODUÇÃO}

O presente artigo objetiva estudar a possibilidade de aplicação da justiça restaurativa na tutela coletiva extrajudicial pelo Ministério Público do Trabalho (MPT) em irregularidades trabalhistas noticiadas à instituição ministerial. Assim sendo, a pergunta problema do trabalho é: em que medida o Ministério Público do Trabalho é uma instituição apta a aplicar as práticas restaurativas nos procedimentos por ele instaurados? Levanta-se a hipótese de que o MPT é um ator político-burocrático com poderes para instaurar procedimentos dialógicos para proceder à concretização de direitos sociais, à harmonização e à pacificação social, sendo as práticas restaurativas um desses procedimentos.

Para verificar a hipótese levantada, analisam-se a estrutura e as formas de aplicação da justiça restaurativa, investiga-se a atuação do Ministério Público do Trabalho, relata-se o desenvolvimento da justiça restaurativa no âmbito do Ministério Público e propõe-se a aplicação das práticas restaurativas pelo Ministério Público do Trabalho.

Utiliza-se o método de abordagem hipotético-dedutivo: propõe-se uma hipótese para o problema e tenta-se averiguá-la ao longo do trabalho. Como método de procedimento, adota-se a pesquisa bibliográfica, que objetiva a obtenção de dados e de argumentos a fim de corroborar ou desqualificar a hipótese levantada.

Primeiramente, faz-se a análise da estrutura da justiça restaurativa, expondo-se algumas formas de sua aplicação. Para tanto, demonstram-se os focos, os objetivos, os pilares, os elementos e os três principais modelos de práticas restaurativas - a vítima-ofensor, as conferências de grupos familiares e os processos circulares.

Em seguida, investiga-se a atuação do Ministério Público do Trabalho enquanto ator político-burocrático com poderes para instaurar procedimentos dialógicos tendo em vista 
a concretização de direitos sociais e de políticas públicas e a harmonização e a pacificação social.

Posteriormente, relata-se o desenvolvimento da justiça restaurativa no âmbito do Ministério Público (MP) com base na análise da Resolução n. ${ }^{\circ}$ 118/2014 do Conselho Nacional do Ministério Público (CNMP), que dispõe acerca da Política Nacional de Incentivo à Autocomposição, examinando-se especialmente os artigos em que se estatuem as práticas restaurativas.

Por fim, propõe-se a aplicação das práticas restaurativas pelo Ministério Público do Trabalho, elucidando algumas questões relativas às técnicas restaurativas, bem como se apresentam algumas críticas e sugestões, que possibilitarão uma análise da justiça restaurativa aplicada às tutelas extraprocessuais trabalhistas, de caráter coletivo.

\section{JUSTIÇA RESTAURATIVA}

Segundo fontes históricas e antropológicas, há vestígios do que hoje chamamos "práticas restaurativas" em algumas comunidades da África, da Nova Zelândia, da Áustria e das Américas. Todavia, algumas dessas práticas foram sufocadas pelas diversas dominações que esses povos sofreram e muitas sumiram devido à centralização do poder estatal dominante (JACCOUD, 2005, p. 163-164).

A inspiração do modelo restaurativo atual remonta às tradições ancestrais dos Maoris, da Nova Zelândia, e das culturas indígenas do Canadá (PINTO, 2005, p. 23). Na Nova Zelândia, a justiça restaurativa começou a ganhar os contornos que hoje conhecemos, destacando-se no âmbito do direito penal nas infrações infantojuvenis, como um modo de lidar com crimes de menor potencial ofensivo ou crimes patrimoniais. Todavia, foi a partir da experiência observada na África do Sul com as Comissões de Verdade e Reconciliação que as estruturas da justiça restaurativa foram ampliadas e começaram a ser aplicadas em situações de violência generalizada (ZEHR, 2015, p. 12).

A justiça restaurativa é uma aproximação que privilegia toda forma de ação, individual ou coletiva, visando (1) corrigir as consequências vivenciadas por ocasião de uma infração, (2) estimular a resolução de um conflito ou a reconciliação das partes ligadas a um conflito, (3) criar um sentimento de responsabilidade pelos atos praticados e (4) gerar um compromisso para cada um dos envolvidos (JACCOUD, 2005, p. 169).

A preocupação especial da justiça restaurativa refere-se às necessidades da vítima, dentre as quais se destacam as seguintes: (1) obter informação, isto é, obter respostas reais quanto às questões ligadas aos atos lesivos sofridos e ao ofensor; (2) dizer a verdade, ou seja, ter a oportunidade de narrar o acontecido a partir da sua perspectiva; (3) recuperar o empoderamento, para que lhe seja devolvido o controle sobre todos os aspectos da sua vida; (4) conseguir a restituição patrimonial ou vindicação por parte daquele que the causou o dano (ZEHR, 2015, p. 28-29).

0 segundo maior foco é garantir que os ofensores assumam responsabilidades. A verdadeira responsabilização estimula o ofensor a compreender as consequências de seus atos 
e incentiva o sentimento de corresponsabilização pelo sofrimento alheio, instigando o ofensor a adotar medidas corretivas quando for possível (ZEHR, 2015, p. 30-31).

Assim, a justiça deve ofertar àquele que causou o dano: (1) a responsabilização por seus atos, para que ele cuide dos danos causados; (2) o estímulo a empatia e a responsabilização social para que ele transforme a vergonha sentida pela percepção do erro; (2) o estímulo à experiência de transformação a partir daquele ato, a ponto de curar os males que corroboraram para que ele agisse daquele jeito, permitir o tratamento de problemas conexos e aprimorar suas competências pessoais; (3) o estímulo e o apoio para a reintegração dele à comunidade; (4) a detenção, se for o caso (ZEHR, 2015, p. 31).

Os pilares da justiça restaurativa são: danos e necessidades, obrigações e engajamento ${ }^{4}$. A justiça restaurativa foca o dano cometido, pois vê o crime como um dano causado às pessoas e à comunidade 5 . Desses danos resultam obrigações que criam responsabilizações para aqueles que os causaram, fazendo que com os ofensores compreendam as consequências de seus comportamentos e assumam o compromisso de corrigir a situação criada, na medida do possível. Assim, a justiça restaurativa promove o engajamento e a participação de todos os afetados (ZEHR, 2015, p. 38-40).

Um dos objetivos da justiça restaurativa é tratar do ato lesivo (dano), sendo um estímulo ao ofensor para que faça o certo. Isso implica, necessariamente, uma responsabilidade para o ofensor, que deve tentar, tanto quanto possível, reparar o dano em todas as suas dimensões: patrimonial, social, intelectual, psicológica etc. Salienta-se que, em primeiro lugar, a obrigação de reparar o dano causado é do ofensor, porém a comunidade, em alguns casos, também pode ser responsável (ZEHR, 2015, p. 44-45).

A dispersão e o compartilhamento do poder de decidir sobre questões elementares da vida dos agentes são fundamentais para a transformação social. O protagonismo dos sujeitos e a abertura à diversidade de narrativas completam e complexificam a imagem do Estado e de seus cidadãos (ARAÚJO, 2019, p. 285).

Outro objetivo é tratar as causas que levaram à ofensa. Para isso, faz-se necessário examinar os danos que o próprio ofensor sofreu, pois muitos atos ilícitos surgem como respostas a uma sensação de vitimização e a um esforço para reverter tal situação (ou surgem de necessidades não atendidas). 0 trauma pode ser considerado uma experiência central na vida de todos (vítima, ofensor e comunidade). Os esforços para reparar o mal é o cerne da

4 De acordo com Zehr (2008, p. 178), a experiência de justiça é uma necessidade humana básica, sem a qual a cura e a reconciliação são difíceis de serem obtidas ou até impossíveis. Portanto, a justiça é precondição para a solução (a administração e a transformação de conflitos, de problemas e de insatisfações sociais (CPIS)). Observa-se que não é objetivo do autor, ao menos nessa obra, conceituar necessidade humana básica, porém adota-se a teoria das necessidades desenvolvida pelos autores Doyal e Gough (1994), segundo a qual existem necessidades básicas comuns, universais e objetivas. 0 critério utilizado para distinguir necessidades humanas básicas das intermediárias ou das preferências foi o impacto negativo (danos graves) causados pelo não atendimento de tais necessidades principalmente no que concerne à saúde física e mental. Assim, Doyal e Gough (1994) defendem que existem duas necessidades básicas: a saúde física e a autonomia racional (autonomia de agência e autonomia crítica). Sucintamente, a autonomia de agência é a capacidade de agir e ser responsável por seus atos, ao passo que a autonomia crítica é a capacidade de participar de processos de avaliação da cultura em que se está inserido, compreendendo-a e alterando-a, se necessário. Ademais, as necessidades humanas básicas compreendem outras onze necessidades intermediárias que as otimizam: a) alimentação nutritiva e água potável; b) habitação adequada; c) ambiente de trabalho desprovido de riscos; d) ambiente físico saudável; e) cuidados de saúde apropriados; f) proteção à infância; g) relações primárias significativas; h) segurança física; i) segurança econômica; j) educação apropriada; k) segurança no planejamento familiar.

5 Em razão do corte metodológico, apesar de haver fortes diferenças conceituais entre comunidade e sociedade, será aqui utilizado o primeiro termo para representar a comunidade ou a coletividade, por significar melhor a ideia defendida. Para aprofundar o tema, consultar o texto El retorno a la comunidad: problemas, debates y desafíos de vivir juntos, de Alfonso Torres Carrillo (2013). 
justiça restaurativa sob duas dimensões: a) tratar suas causas, inclusive os fatores negativos que possibilitaram o comportamento ilícito; b) tratar os danos cometidos (ZEHR, 2015, p. 46-48).

Figura 1 - Justiça restaurativa.

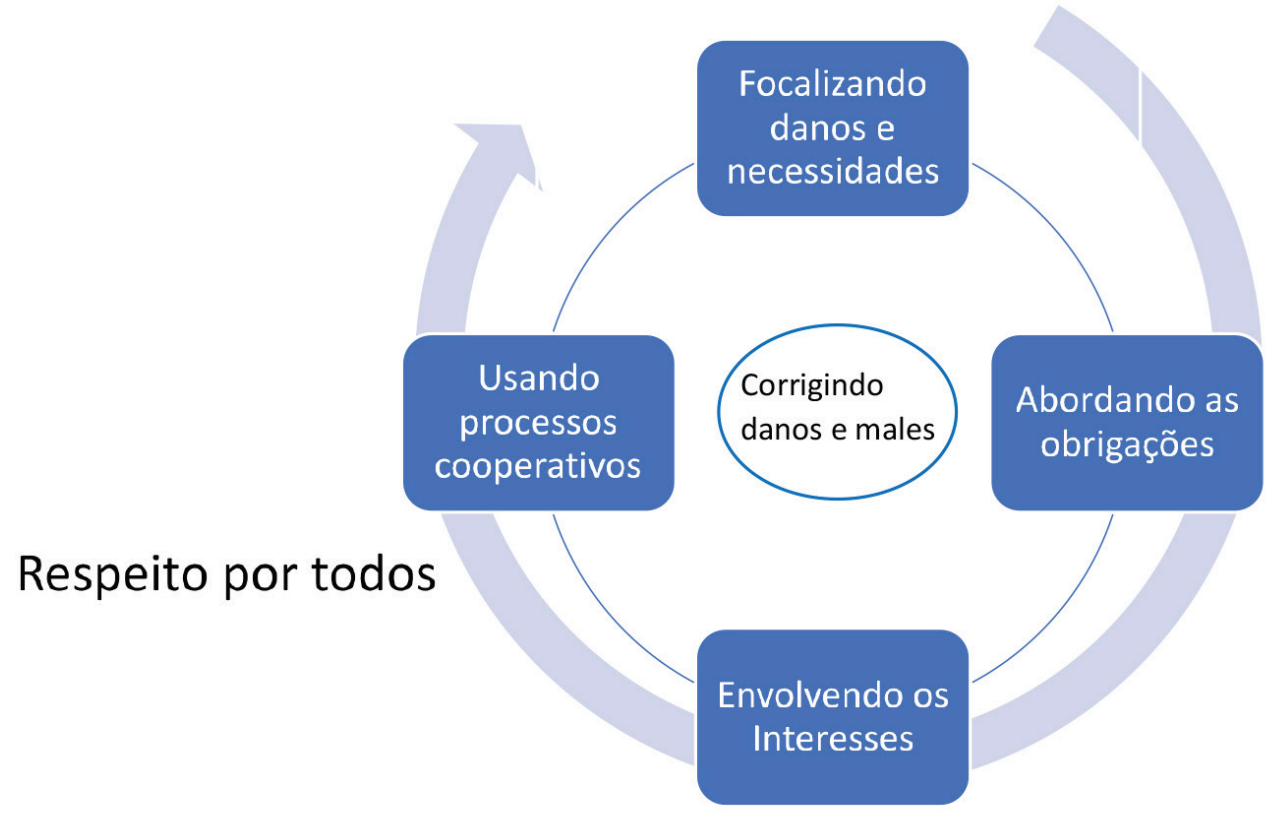

Fonte: ZEHR, 2015, p. 50.

A questão central do processo restaurativo é corrigir os sérios prejuízos (graves danos) ${ }^{6}$ provenientes do ato lesivo. Para tanto, a justiça restaurativa adota algumas medidas: a) foca as necessidades e os danos dos envolvidos para analisar pretensões, expectativas, medos, frustrações e outros; b) envolve os interesses de todos; c) aborda as obrigações que todos os envolvidos possuem diante dos CPIS; d) faz uso, para chegar ao resultado esperado, de processos cooperativos para criar ou restabelecer um elo entre os sujeitos envolvidos, bem como (re)criar o sentimento de responsabilidade pelo atos individuais para com os outros. Salienta-se que todo esse trabalho é marcado pelo respeito mútuo entre os participantes, em clima cooperativo e não adversarial.

Há três modelos principais de práticas restaurativas: os encontros vítima-ofensor, as conferências de grupos familiares e os processos circulares. Cada um implica, em alguma medida e indissociavelmente, o diálogo entre os interesses dos envolvidos. Todos partem do pressuposto de que, para resolver todo e qualquer comportamento nocivo, é preciso, primeiramente, atender a três premissas: (1) o mal cometido precisa ser conhecido por todos; (2) a equidade 7 precisa ser criada ou restaurada; (3) é preciso tratar das intenções futuras

6 Doyal e Gough (1994, p. 50) utilizam a expressão "graves danos" (serious harm) para referir-se aos impactos negativos que impedem ou põem em sério risco a possibilidade objetiva de os seres humanos viverem física e socialmente em condições de poder expressar sua capacidade ativa crítica.

7 Zehr, nas obras Trocando as lentes (2008) e Justiça restaurativa (2015), não apresenta um conceito jurídico-filosófico de equidade, apenas a apresenta como um valor a ser buscado pela justiça restaurativa. Porém, salienta-se que o uso discricionário do termo pode levar a errôneas compreensões, uma vez que diversos autores, como Aristóteles (Ética à Nicômaco), John Rawls (Uma teoria da justiça) e Ronald Dworkin (O império do direito), conceituaram-na diferentemente. Embora haja certo senso comum jurídico em abordar a equidade como a justiça do caso concreto, o que remontaria ao conceito aristotélico, tal conceituação é equivocada ao ignorar a antropologia e a metaética que dão subsídio ao conceito. Cordioli (2015, p. 185-209) esclarece que muitas teorias de justiça atuais, como a de Rawls, deixaram de considerar o papel da ética e das 
de todos. Ademais, em todos os modelos, a participação das pessoas deve ser voluntária (ZEHR, 2015, p. 62-63).

Os encontros entre vítima e ofensor envolvem os diretamente prejudicados e os responsáveis pelo dano. A priori, a vítima e o ofensor devem ser separados, mas, havendo consentimento para que haja o encontro entre os dois, o procedimento restaurativo deve ser organizado e conduzido por um facilitador que orientará o processo de modo equilibrado (ZEHR, 2015, p. 66).

Em uma das fases, oferece-se à vítima a oportunidade de reunir-se com o infrator em ambiente seguro e estruturado, acompanhado de facilitadores, para um enfrentamento (ou melhor, um espaço cooperativo) em que ambos podem construir um plano restaurativo para abordar o conflito e resolvê-lo (transformá-lo ou administrá-lo) (PAZ, S.; PAZ, M., 2005, p. 127).

Nas conferências de grupos familiares, ocorre a ampliação dos participantes, incluindo, necessariamente, familiares e outras pessoas da comunidade envolvidas diretamente no conflito. Tal modelo concentra-se em oferecer apoio àqueles que sofreram o dano e à família, bem como a quem causou o dano e a sua família (ZEHR, 2015, p. 66-67). Os objetivos das conferências são envolver a vítima na construção da resposta ao delito, conscientizar o infrator da maldade de seus atos e vincular a vítima e o infrator à comunidade (PAZ, S.; PAZ, M., 2005, p. 127).

Os círculos de construção de paz são um processo de diálogo que cria intencionalmente um espaço em que as pessoas possam sentir-se seguras para discutir problemas difíceis ou dolorosos, com o intuito de melhorar os relacionamentos e resolver as diferenças. A intenção do círculo é pensar em soluções que se coadunam com cada membro participante. 0 processo baseia-se na suposição de que cada participante do círculo tem igual valor e dignidade, garantindo-se o direito de participação a todos, pois compreende-se que cada participante possui dons a oferecer na busca de uma boa solução para o problema (PRANIS, 2010, p. 11).

Os círculos são preconcebidos para debater como a conversa acontecerá antes de discutir os assuntos difíceis. Consequentemente, para a consecução desse encontro, o círculo estuda os valores e diretrizes antes de abordar as diferenças ou os conflitos (ou melhor, conflitos, problemas ou insatisfações sociais (CPIS)). Quando possível, o círculo também examina a construção dos relacionamentos antes de discutir os assuntos difíceis. A responsabilidade do facilitador, nesses casos, é auxiliar os participantes a criar uma zona segura para a conversa e monitorar a qualidade do espaço (e do diálogo) durante a realização do círculo. Portanto, se o ambiente se tornar desrespeitoso, o facilitador deve chamar a atenção do grupo para esse problema e ajudá-lo a restabelecer o espaço de respeito (PRANIS, 2010, p. 11).

No Brasil, a Justiça Restaurativa começou a ser oficialmente aplicada em 2005 com três projetos-piloto implantados no Estado de São Paulo, no Estado do Rio Grande do Sul e no Distrito Federal. Atualmente, os programas, projetos e ações em Justiça Restaurativa

pessoas e focaram suas análises na política e nas instituições sociais. Contudo, a equidade, em Aristóteles, é uma virtude ética que é uma das modalidades da justiça, enquanto retificação do justo legal. Isto é, um atributo desejável de caráter que leva a pessoa a querer o justo não apenas no sentido da lei, mas que o ultrapassa quando o último se mostra contra a igualdade e o bem comum. Sendo assim, não há como separar o conceito de equidade em Aristóteles dos conceitos de virtude, vício, justiça, igualdade e bem comum. 
são, em regra, coordenados e promovidos pelo Poder Judiciário e as metodologias restaurativas mais utilizadas são os círculos de construção de paz de Kay Pranis e os baseados em comunicação não-violenta. Apesar da expansão, a aplicação se restringe as infrações criminais leves, aos atos infracionais e a violência doméstica, embora haja um alto interesse por desenvolvimento de capacitação e ações restaurativas em direito de família (CONSELHO NACIONAL DE JUSTIÇA, 2019, p. 5, 39).

Após a análise da justiça restaurativa, demonstrados os três principais modelos de práticas restaurativas, analisemos a atuação do Ministério Público do Trabalho, enquanto instituição apta a promover a harmonização social por meio da busca da efetivação dos direitos sociais.

\section{ATUAÇÃO DO MINISTÉRIO PÚBLICO DO TRABALHO}

A Constituição da República Federativa do Brasil (CRFB) de 1988 garantiu que o Ministério Público se estruturasse com profissionalismo, especialização de atuação e um corpo burocrático como o poder de cumprir a missão constitucional de concretizar direitos humanos (ACKERMAN, 2000, p. 692).

O Ministério Público, então, é uma instituição burocrática com poderes para formular argumentos no intuito de deliberar e de discutir, em igualdade de condições, com os interessados e os envolvidos em CPIS, na busca de um acordo deliberativo fundamentado que atenda à justiça (SILVA, 2016, p. 241).

No intuito de ampliar o alcance da instituição, a CRFB/1988 burocratizou o Ministério Público em duas esferas federativas: a União e os estados. Assim, para a concretização e a realização dos direitos sociais, o Ministério Público da União abrange o MP federal, o do Distrito Federal e territórios, o militar e o do trabalho (SILVA, 2016, p. 248).

Logo, o Ministério Público é um ator político-burocrático que tem poderes para instaurar procedimentos dialógicos para proceder à especificação e à concretização de direitos sociais de forma a torná-los exigíveis no campo individual e coletivo (SILVA, 2016, p. 78-79). O MPT adota diversos procedimentos administrativos (ou melhor, ministeriais) ${ }^{8}$ que possibilitam a sua atuação (Figura 2).

8 Apesar de serem denominados "procedimentos administrativos", considera-se que tal denominação é uma forma de ler o novo com lentes antigas, pois o Ministério Público possui autonomia constitucional e atua independentemente dos demais ramos do Poder Público. Portanto, a classificação escorreita é ato, procedimento ou negociação ministerial quando se tratar do exercício da atribuição típica do Ministério Público, sem que isso afaste a possibilidade de atribuições atípicas, como atos e processos administrativos de nomeação, exoneração de servidores e membros, entre outros (SILVA, 2016, p. 276). 
Figura 2 - Procedimentos administrativos do MPT.

\begin{tabular}{c|c}
\hline PROCEDIMENT0 & SIGLA \\
\hline Carta Precatória do Ministério Público & CP \\
\hline Inquérito Civil & IC \\
\hline Notícia de Fato & NF \\
\hline Procedimento de Acompanhamento Judicial & PAJ \\
\hline Procedimento Administrativo de Mediação & PA-MED \\
\hline Procedimento Administrativo de Arbitragem & PA-ARB \\
\hline Procedimento Administrativo Promocional & PA-PROM0 \\
\hline Procedimento Preparatório & PP \\
\hline
\end{tabular}

Fonte: Elaboração dos autores.

Cada um desses procedimentos possui uma finalidade e um objeto distinto, o que não será posto em debate neste artigo ${ }^{9}$. Portanto, observa-se que o MPT dispõe de diversos instrumentos de concretização de direitos humanos sociais, de políticas públicas e de harmonização e pacificação social, dentre os quais se destacam o inquérito civil, o acordo de concretização de direitos humanos ou termo de ajustamento de conduta ${ }^{10}$, a recomendação, o procedimento de promoção de políticas públicas, os procedimentos administrativos de mediação e de arbitragem (SILVA, 2016, p. 78).

Essa forma de atuação ministerial, voltada para a defesa do interesse público e das demandas sociais, em comparação, por exemplo, com os parâmetros materiais de legitimidade da intervenção judicial em políticas públicas (SOUZA NETO, 2008, p. 125), atende aos critérios de atuação em tais políticas de forma mais flexível, com a defesa dos hipossuficientes, permitindo (1) a participação do indivíduo na autonomia privada e coletiva, (2) a universalização das medidas sociais, garantindo acesso simultâneo, igual e universal, (3) a consideração do sistema dos direitos sociais em sua unidade, (4) a primazia da opção técnica e administrativa (em caso de divergência) e da solução mais econômica (relação custo-benefício) e (5) o exercício do controle da execução orçamentária das políticas públicas (SILVA, 2016, p. 80).

Em 2015, no Ministério Público do Trabalho do Pará (MPT-PA), Procuradoria Regional do Trabalho da 8. ${ }^{a}$ Região Pará e Amapá, na sede em Belém, foram instaurados 1.777 (mil setecentos e setenta e sete) procedimentos, os quais foram distribuídos aos 19 (dezenove) ofícios que compõem o órgão ministerial regional da $8{ }^{a}$ Região ${ }^{11}$. Com base nos dados totais obtidos na pesquisa, fez-se um levantamento dos procedimentos (Figura 3).

9 Para saber mais acerca dos procedimentos ministeriais, ver a obra O Ministério Público e a concretização dos direitos humanos, de Sandoval Alves da Silva (2016).

10 De acordo com Silva (2016, p. 303-305), a palavra "termo" faz referência a um documento de formalização e não ao acordo em si; a palavra "ajustamento" significa o ato ou o efeito de ajustar as ações, mas o planejamento do atendimento de um direito social não precisa necessariamente advir de algo desajustado; a menção a "conduta" provém da crença de que é necessário consertar o que está errado. Por isso, propõe-se o nome "acordo de concretização de direitos humanos" (ACDH), por ser mais condizente com as funções ministeriais resolutivas, e esse acordo será formalizado pelo "termo de acordo de concretização de direitos humanos" (TCDH).

11 Dados obtidos a partir da pesquisa PIBIC vinculada à Faculdade de Direito da Universidade Federal do Pará (UFPA) referente ao projeto de pesquisa $A$ resolutividade dos problemas e conflitos coletivos por meios processuais e extraprocessuais instaurados pelo ministério público, que pesquisou os procedimentos instaurados pelo Ministério Público do Trabalho do Pará no ano de 2015. 
Figura 3 - Procedimentos abertos pelo MPT-PA em 2015.

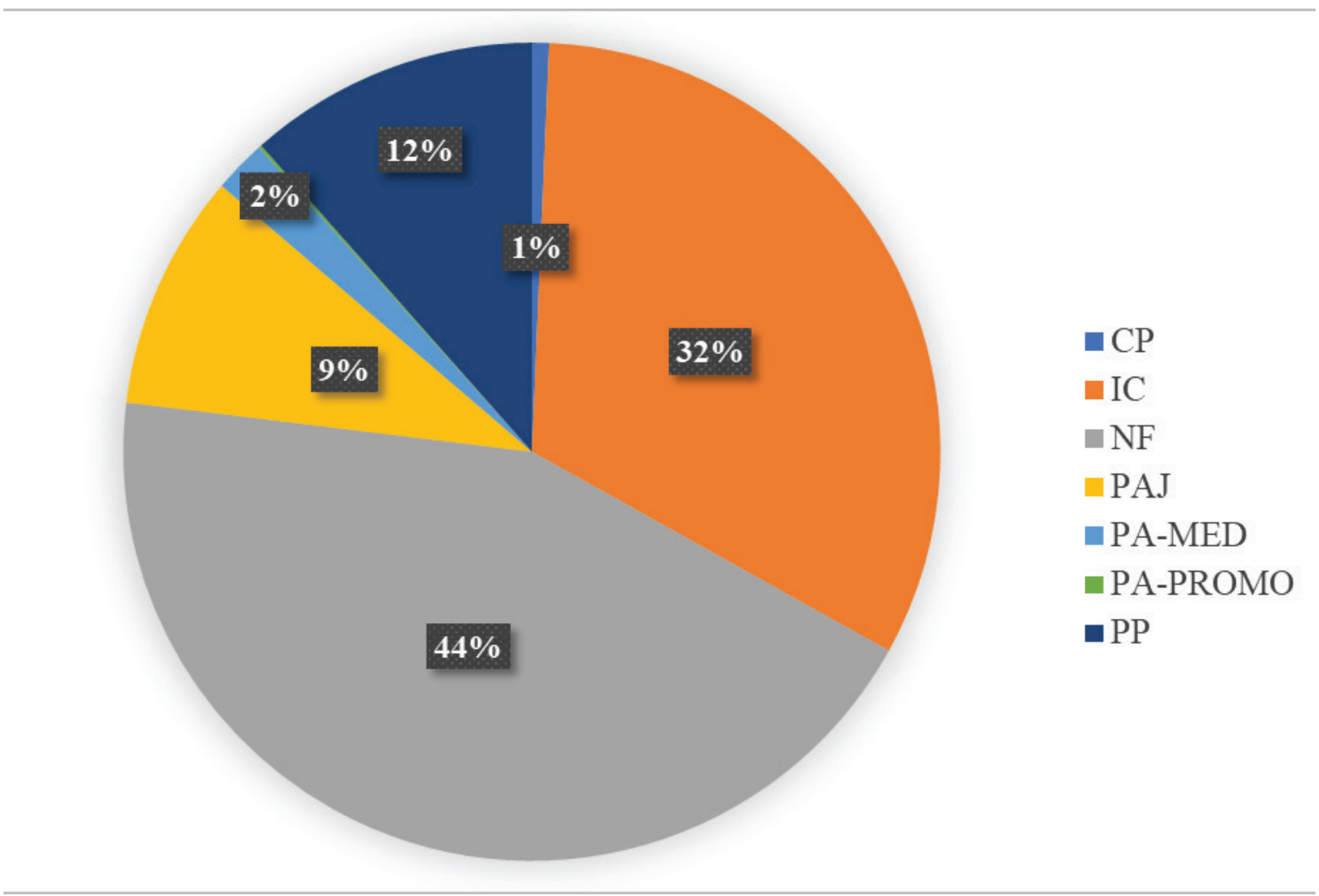

Fonte: Elaboração dos autores.

Observa-se que $44 \%$ (quarenta e quatro por cento) dos procedimentos instaurados pelo MPT-PA em 2015 foram Notícias de Fato (NF) de irregularidades que chegavam ao órgão por meio de informações dadas por trabalhadores, por terceiros interessados, pelo ConseIho Tutelar, pelo Disque 100, vinculado, na época, ao Ministério dos Direitos Humanos (hoje denominado Ministério da Mulher, da Família e dos Direitos Humanos), e por diversos outros órgãos.

Algumas NF foram convertidas em Inquéritos Civis (IC), contabilizando $32 \%$ (trinta e dois por cento) dos procedimentos instaurados. Em seguida, o terceiro procedimento mais instaurado foram os Procedimentos Preparatórios (PP) para instauração de IC, totalizando 12\% (doze por cento). Os Procedimentos de Acompanhamento Judicial (PAJ) representam 9\% (nove por cento) dos procedimentos de 2015, sendo o quarto procedimento mais instaurado pelo ente. Por fim, com $2 \%$ (dois por cento) e 1\% (um por cento), respectivamente, estão os Procedimentos de Mediação (PA-MED) e as Cartas Precatórias (CP) do Ministério Público.

Assevera-se que, entre os procedimentos instaurados, 2 (dois) foram Procedimentos Ministeriais Promocionais (PA-PROMO), uma quantidade pequena comparada aos demais procedimentos, por isso não entrou no gráfico acima. Tampouco houve Procedimentos de Arbitragem (PA-ARB) instaurados no ano de 2015. Assim sendo, constata-se que inexiste no Ministério Público um procedimento específico para os procedimentos restaurativos que utilizem os métodos empregados pela justiça restaurativa. 
Todavia, isso não significa que os procedimentos restaurativos não sejam aplicados no âmbito do MPT, pois há relatos da utilização pela Procuradoria Regional do Trabalho da $8 .^{a}$ Região Pará e Amapá, como será explorado nas seções seguintes.

\section{JUSTIÇA RESTAURATIVA NO ÂMBITO DO MINISTÉRIO PÚBLICO}

Em 2014, o Conselho Nacional do Ministério Público (CNMP) editou a Resolução n. ${ }^{\circ}$ 118, que dispõe sobre a Política Nacional de Incentivo à Autocomposição, que considera a negociação, a mediação, a conciliação, as convenções processuais e as práticas restaurativas instrumentos efetivos de pacificação social, de resolução e de prevenção de litígios, de controvérsias e de problemas. Somada a isso, a apropriada utilização tem reduzido a excessiva judicialização e tem satisfeito os envolvidos (CONSELHO NACIONAL DO MINISTÉRIO PÚBLICO, 2015, p. 1-2).

Observa-se que a Resolução salienta que as práticas restaurativas têm-se demonstrado um efetivo instrumento para a pacificação social, a resolução, a administração ou a transformação de conflitos, de problemas e de insatisfações sociais (CPIS) ${ }^{12}$, bem como reduziram a judicialização das demandas, empoderando e satisfazendo os envolvidos. Com base nessa indicação, podem-se fazer duas asserções: (1) os demais meios, que não o processo judicial, podem ser efetivos na resolução, administração e transformação de CPIS 13; (2) os meios de resolução, de administração e de gestão de conflitos também são capazes de promover o acesso à justiça ${ }^{14}$, independentemente do acesso ao Poder Judiciário.

Essa perspectiva demonstra que o Ministério Público, incluindo o do Trabalho, busca, em sua atuação, sedimentar a cultura da paz que priorize o diálogo e o acordo na resolução dos CPIS. Para tanto, o CNMP poderá, inclusive, realizar pesquisas sobre os processos administrativos (ou melhor, ministeriais) no âmbito de suas atividades, bem como divulgá-las aos demais membros do Ministério e à sociedade (artigo 6. ${ }^{\circ}$, incisos IV e V, da Resolução n. ${ }^{\circ}$ 118/2014) $)^{15}$ (CONSELHO NACIONAL DO MINISTÉRIO PÚBLICO, 2015, p. 2).

12 Compreende-se que nem todos os conflitos, problemas e insatisfações sociais (CPIS) são solucionáveis, alguns conseguem ser apenas administráveis enquanto perduram e outros podem ser transformados, isto é, pode-se estimular que as mudanças sejam construtivas a partir do conflito. Essa perspectiva pode ser aprofundada no artigo Acesso à justiça no Projeto "Escrevendo e Reescrevendo a Nossa História" (Pernoh) (SILVA; SIQUEIRA, 2020).

13 No que se refere à expressão "meios alternativos" ou às palavras "complementar" e "alternativo", registra-se a controvérsia doutrinária e a possível impropriedade técnica, por valorizarem apenas a via jurisdicional. Do mesmo modo, a palavra "adequado" pode implicar igualmente atecnia, prestigiando a via autocompositiva, em detrimento da jurisdicional. Assim, quando se utiliza "alternativa", entende-se que se está supervalorizando o Judiciário; por outro lado, quando se opta por "adequado", está-se subvalorizando-o. Essa perspectiva pode ser aprofundada no artigo A sociedade e a solução de conflitos negociados (SILVA, 2019).

14 Compreende-se que o acesso à justiça não significa apenas acesso ao Judiciário, visto que o acesso à justiça implica acesso à cidadania e acesso à participação democrática nos rumos da sua própria vida em comunidade. Essa perspectiva pode ser vista no livro Mediação nos conflitos civis, de Fernanda Tartuce (2015), e no artigo 0 (in)acesso à justiça com a demolidora reforma trabalhista, de Sandoval Alves da Silva (2017).

15 Art. $6^{\circ}$ Para consecução dos objetivos supracitados, o CNMP poderá: [...] IV - Realizar pesquisas sobre negociação, mediação, conciliação, convenções processuais, processos restaurativos e outros mecanismos autocompositivos; $V$ - Promover publicações sobre negociação, mediação, conciliação, convenções processuais, processos restaurativos e outros mecanismos autocompositivos. 
Essa mudança de perspectiva do Ministério Público adveio da ponderação da atuação judicial da instituição com uma atuação processual demandista ${ }^{16}$ em detrimento da atuação extraprocessual, pois a atividade processual consome a atividade ministerial, tirando-Ihe tempo ${ }^{17}$ de envolver-se na resolução de CPIS no campo da extraprocessualidade (SILVA, 2016, p. 244). A atuação resolutiva do Ministério Público é uma das formas de efetivar o acesso à justiça ${ }^{18}$, uma tentativa de esgotar as possibilidades extrajudiciais de resolução (administração e transformação) das questões que Ihe são noticiadas (MIRANDA, 2010, p. 373).

A Resolução versa especificamente sobre justiça restaurativa em dois dispositivos: no artigo $13^{19}$ e no artigo $14^{20}$. 0 primeiro afirma que as práticas restaurativas são recomendadas nas situações em que é viável a reparação dos efeitos da infração pela harmonização entre as partes, visando restaurar o convívio social e pacificar os relacionamentos. 0 segundo informa que, nas práticas restaurativas, o infrator, a vítima e quaisquer outras pessoas ou setores, públicos ou privados, da comunidade afetada, com o auxílio de um facilitador, participarão conjuntamente de encontros, objetivando a formulação de um plano restaurativo para a reparação ou a minoração do dano, a reintegração do infrator e a harmonização social (CONSELHO NACIONAL DO MINISTÉRIO PÚBLICO, 2015, p. 7).

Constata-se que ambos os artigos tratam de forma geral os procedimentos restaurativos, sem pormenorizá-los. 0 artigo 13 enfatiza que tais práticas são recomendadas apenas para algumas situações; logo, nem todo caso que chega ao Ministério Público é apto à justiça restaurativa. 0 próprio artigo menciona o requisito que possibilita a sua utilização: quando observada a viabilidade da reparação dos efeitos da infração pela harmonização entre os envolvidos.

Todavia, Zehr (2015, p. 19-20) salienta que a justiça restaurativa não tem como escopo fundamental o perdão ou a reconciliação, apesar de serem necessários, em certa medida; nem requer, necessariamente, a volta do status quo ante bellum, visto que o retorno ao passado, em muitos casos, não é possível, algumas situações necessitam ser transformadas ${ }^{21}$ e não restauradas. Logo, a justiça restaurativa não significa um retorno ao estado pré-conflito.

16 Macêdo (2013, p. 341) caracteriza o modelo demandista como o que faz uso das demandas judiciais cíveis e criminais na resolutividade dos conflitos, seja como demandante, seja como interveniente.

17 Salienta-se que, embora haja uma preocupação com a demora que o Poder Judiciário leva para solucionar um conflito, um problema ou uma insatisfação social, não se pode afirmar que a celeridade é sempre positiva, posto que a razoabilidade da duração do processo não significa necessariamente efetividade, nem que os métodos autocompositivos são uma alternativa à demora do Judiciário por serem mais céleres. A título de exemplo, metodologias como os círculos de construção de paz, classificadas como autocompositivas, exigem bem mais tempo e esforços dos envolvidos. Logo, não se pode afirmar categoricamente que os meios autocompositivos são necessariamente mais céleres. Essa perspectiva pode ser aprofundada em Silva e Siqueira (2020).

18 Para Tartuce (2015, p. 77-78), o cerne do acesso à justiça não é possibilitar a ida de todos ao tribunal, mas permitir que a justiça seja realizada no contexto em que as pessoas estão inseridas. No processo democrático, o acesso à justiça desempenha relevante papel ao habilitar o cidadão a tutelar seus interesses e ao possibilitar à sociedade a autocomposição pacífica de conflitos (problemas e insatisfações sociais)

19 Art. 13. As práticas restaurativas são recomendadas nas situações para as quais seja viável a busca da reparação dos efeitos da infração por intermédio da harmonização entre o (s) seu (s) autor (es) e a (s) vítima (s), com o objetivo de restaurar o convívio social e a efetiva pacificação dos relacionamentos.

20 Art. 14. Nas práticas restaurativas desenvolvidas pelo Ministério Público, o infrator, a vítima e quaisquer outras pessoas ou setores, públicos ou privados, da comunidade afetada, com a ajuda de um facilitador, participam conjuntamente de encontros, visando à formulação de um plano restaurativo para a reparação ou minoração do dano, a reintegração do infrator e a harmonização social.

210 termo "transformação" de conflitos expressa a procura por formas de estimular mudanças construtivas a partir do conflito. Essa corrente teórica afirma-se como não idealista nem utópica, visto que busca resultados práticos advindos dos métodos de transformação do conflito. A transformação de conflitos passa pela visualização e pela reação aos "altos e baixos" do conflito enquanto oportunidade vivificante de criar processos construtivos de mudanças, que diminuam a violência 
Ademais, em nosso sentir, nem o efeito ex tunc faz isso, pois a ocorrência do trauma, do conflito, do problema ou da insatisfação social já alterou o estado das coisas, dos relacionamentos, dos sentimentos, da psiquê humana etc., de forma que mesmo a restauração do bem lesado, a recomposição integral do dano ou de seus efeitos não têm o condão de retirar do mundo dos fenômenos a sua ocorrência, como se nada tivesse ocorrido, razão pela qual a ideia de retornar ao estado pré-conflito mostra-se viável apenas no mundo ideal.

O artigo 14, ao empregar os termos "infrator" e "vítima", parece fazer alusão a um dos procedimentos da justiça restaurativa: a conferência vítima-ofensor. Todavia, por ser um artigo aberto, percebe-se que houve apenas uma atecnia no emprego das palavras, uma vez que alguns procedimentos optam por usar termos como "participantes", "envolvidos" e outros, por serem mais genéricos e menos estigmatizantes ${ }^{22}$.

Ademais, o mesmo artigo, ao mencionar os possíveis participantes do procedimento restaurativo, omite a comunidade enquanto participante fundamental no processo de restauração. Para Araújo (2019, p. 285), na justiça restaurativa, o envolvimento dos sujeitos (inclusive da comunidade) nos processos deliberativos ou dialógicos é acompanhado da responsabilização pelas causas, pelos resultados e pela execução das ações planejadas.

O envolvimento da comunidade é de suma importância para a efetividade da harmonização proveniente das práticas restaurativas. Por um lado, a comunidade é o pano de fundo de muitos conflitos (ou melhor, conflitos, problemas e insatisfações sociais (CPIS)). Por outro, as ferramentas que as comunidades utilizam para tratá-los podem auxiliar o Estado a ampliar sua compreensão de justiça e as estratégias para satisfazê-la. Assim, embora o Estado seja um apoiador relevante, os conflitos que conduzem para discussões públicas costumam estar circunscritos à esfera privada. Portanto, o fazer justiça "na, para e pela comunidade" não é centrado na figura do Estado (ARAÚJO, 2019, p. 285-287).

Assim sendo, as comunidades também sofrem os impactos da desarmonia social e, em muitos casos, podem e devem ser consideradas sujeitos interessados no conflito, visto que podem ter responsabilidades em relação aos envolvidos no conflito. Dessa maneira, as comunidades necessitam que a Justiça ofereça (1) atenção às suas preocupações enquanto vítimas da ofensa, (2) oportunidades para delimitar um senso comunitário e de responsabilidade mútua e coletiva e (3) as oportunidades e o encorajamento para que também assumam compromissos para com seus membros (ZEHR, 2015, p. 32).

Outro aspecto importante apresentado no artigo 14 da Resolução é que os participantes reunir-se-ão para a formulação de um plano restaurativo para tratar da reparação ou minoração do dano, da reintegração do infrator e da harmonização social. Esse elemento traduz-se na forma como os CPIS são vistos. De acordo com Araújo (2019, p. 221), os conflitos podem ser vistos de duas formas: uma focal e outra topográfica ${ }^{23}$. A primeira foca exclusi-

e potencializem a justiça nas interações diretas e nas estruturas sociais, bem como respondam aos problemas dos relacionamentos humanos (LEDERACH, 2012, p. 16 e p. 27).

22 Silva (2016, p. 293-294) salienta que o uso das palavras "inquiridos", "investigados", "denunciados" e semelhantes revela vestígios do inquérito penal no inquérito civil público, em uma lógica de acusação, cujo foco principal é a correção e a punibilidade. $\mathrm{O}$ autor sugere uma mudança do foco principal para a concretização dos direitos sociais, das políticas públicas e da harmonização e da pacificação social, adotando-se uma visão preventiva ou prospectiva em atenção às necessidades não atendidas; para tanto, convém fazer uso de palavras como "participantes", "envolvidos" e outras.

23 Lederach (2012, p. 21-23) nos ensina outra forma de observar o conflito. Imagine uma armação de óculos com três lentes, uma mostra de forma nítida o que está longe; a segunda foca o que está a meia distância e a terceira amplia a visão das coisas próximas. Assim, cada lente possui uma função específica e não exercem a função da outra nem a de todas ao mesmo 
vamente as urgências que surgem do conflito, ao passo que a segunda o compreende como uma oportunidade para entender os padrões e modificar as estruturas dos relacionamentos.

Portanto, para mapear um conflito, é importante atentar aos seguintes elementos: a) as características dos sujeitos envolvidos, seus interesses e necessidades; b) as estruturas de poder e os padrões das relações intersubjetivas; $c$ ) as estruturas conceituais que sustentam cada uma dessas perspectivas; d) as compreensões de mundo dos indivíduos e grupos em questão; e) as emoções despertadas pela situação conflitiva (ARAÚJO, 2019, p. 221).

Diante do exposto, apura-se que, para conseguir chegar ao plano restaurativo, tal como almejado na resolução, faz-se necessário observar todos esses elementos descritos acima, pois a desconsideração de qualquer um poderia prejudicar a formulação e a execução do plano restaurativo, uma vez que não consideraria todas as nuances que formam os CPIS. Além disso, os objetivos do plano, de acordo com o CNMP, são: a) reparação ou minoração do dano, b) reintegração do infrator e c) harmonização social.

Tais objetivos estão em consonância com os cinco princípios ou ações-chave da justiça restaurativa: (1) focar, antes de qualquer coisa, as necessidades das vítimas, dos ofensores e da comunidade, bem como os danos por eles sofridos; (2) abordar as obrigações oriundas do dano; (3) fazer uso de processos cooperativos e inclusivos; (4) envolver todos os que possuem interesse na situação; (5) buscar reparar os danos, na medida do possível (ZEHR, 2015, p. 49).

Como exemplo da aplicação da justiça restaurativa pelo Ministério Público, podemos citar dois projetos: "MP Restaurativo e a Cultura de $\mathrm{Paz}^{24}$, desenvolvido pelo Ministério Público do Paraná, e o "Núcleo Permanente de Incentivo à Autocomposição (NUPA)", do Ministério Público do Rio Grande do Norte ${ }^{25}$. Ambos visam implantar as práticas restaurativas na atuação, inclusive extrajudicial, do Ministério Público, por meio de cursos de capacitação para seus membros, elaboração de manuais e de relatórios, criação de núcleos integrados.

Por fim, o artigo $18^{26}$ da Resolução trata da capacitação dos membros e servidores do Ministério Público que serão habilitados pelas instituições competentes para exercer as práticas da justiça restaurativa. Portanto, apenas pessoas devidamente capacitadas devem aplicar tais práticas. Do exposto, extrai-se que as práticas restaurativas devem ser estimuladas no âmbito do Ministério Público, inclusive o do Trabalho, como analisaremos a seguir.

tempo. Tais lentes auxiliam-nos na compreensão da complexidade da realidade e do conflito. A lente que aumenta o objeto próximo é necessária para podermos visualizar a situação imediata. A lente que permite a nitidez de objetos a uma distância média, possibilita a identificações de padrões de condutas de um relacionamento/conflito, bem como o contexto ao qual está inserido. E por fim, a última lente, para longe, possibilita uma visão macro acerca do conflito permitindo criar maneiras de tratá-lo.

24 Para conhecer mais acerca do projeto desenvolvido pelo Ministério Público Estadual do Paraná, acesse o site: http://www. site.mppr.mp.br/modules/conteudo/conteudo.php?conteudo=99.

25 Para conhecer mais acerca do projeto desenvolvido pelo Ministério Público Estadual do Rio Grande do Norte, acesse o site: https://www.mprn.mp.br/portal/inicio/institucional/nupa.

26 Art. 18. Os membros e servidores do Ministério Público serão capacitados pelas Escolas do Ministério Público, diretamente ou em parceria com a Escola Nacional de Mediação e de Conciliação (ENAM), da Secretaria de Reforma do Judiciário do Ministério da Justiça, ou com outras escolas credenciadas junto ao Poder Judiciário ou ao Ministério Público, para que realizem sessões de negociação, conciliação, mediação e práticas restaurativas, podendo fazê-lo por meio de parcerias com outras instituições especializadas. 


\section{JUSTIÇA RESTAURATIVA APLICADA PELO MINISTÉRIO PÚBLICO DO TRABALHO}

A justiça restaurativa visa dar protagonismo aos sujeitos envolvidos, permitindo uma visão holística do conflito, com a participação da comunidade afetada e a restauração das relações. A Resolução n. ${ }^{\circ}$ 118/2014 do CNMP dispõe sobre a Política Nacional de Incentivo à Autocomposição e estimula a realização de práticas restaurativas. Porém, muito se questiona sobre a possibilidade de aplicação de tais práticas nos litígios trabalhistas.

Infere-se que é possível a aplicação da justiça restaurativa na Justiça do Trabalho na tutela extrajudicial coletiva. Os danos coletivos que ocorrem na esfera laboral são muitas vezes fruto de um meio ambiente de trabalho comprometido. Neste contexto, a participação da comunidade é indispensável. O procedimento ordinário em que apenas o trabalhador ingressante e o empresário participam não dá conta desta realidade. De nada adianta estas partes realizarem um acordo quanto aquele problema específico sem modificar o meio ambiente de trabalho que permite a perpetuação de violações semelhantes. Menos efetivo ainda é a judicialização, que muitas vezes ignora a raiz do problema e embora tenha êxito quanto ao reclamado, não atua no aspecto macro. Neste contexto, a justiça restaurativa oferece metodologias de tomada de decisão coletiva em que as partes se conscientizam da sua responsabilidade frente ao conflito e criam coletivamente formas de solucioná-lo ou administrá-lo.

Exemplos de possíveis aplicações são os casos que envolvem o trabalho infantil, o trabalho escravo e os acidentes de trabalho. Quanto a estes últimos, argumenta-se que há uma monetarização da saúde e que casos de Lesão por Esforço Repetitivo (LER) e de Perda Auditiva Induzida por Ruído Ocupacional (PAIR) não são resolvíveis com indenização, visto que decorrentes do meio ambiente de trabalho ${ }^{27}$. Portanto, faz-se necessário restaurar o psicológico (autoestima), o coletivo (ambiente de trabalho e o grupo) e o círculo familiar (como a doença refletiu no seio doméstico e na relação com os amigos) (BARROS, 2006, p. 5).

Com a aplicação da justiça restaurativa nesses casos será possível (1) trazer a comunidade e verificar se os atuais empregados, bem como os já demitidos, apresentam outros problemas decorrentes do meio ambiente de trabalho, (2) prestar assistência médica, psicológica e social aos casos já detectados, (3) adotar medidas preventivas para que o ato lesivo não volte a ocorrer ou não tenha as mesmas consequências e (4) fiscalizar a empresa, acompanhando o cumprimento dos compromissos assumidos (BARROS, 2006, p. 5).

Nesse sentido, alguns autores propõem a criação de uma rede de assistência restaurativa com médicos, assistentes sociais, representantes do Ministério Público do Trabalho (MPT), das Delegacias Regionais do Trabalho (DRT), entre outros (BARROS, 2006, p. 7).

Deve-se esclarecer que as lides trabalhistas que discutem apenas obrigações pecuniárias não devem ser objeto da justiça restaurativa, que deve limitar-se a casos em que é preciso "restaurar" a relação e em que haja consenso das partes (ou melhor, acordo entre os envolvidos), visto que a consensualidade é elemento essencial. Portanto, a justiça restaura-

270 meio ambiente do trabalho decorre da interação ordenada de fatores naturais, técnicos e psicológicos inerentes às condições de trabalho, à organização laboral e às relações interpessoais que condicionam a segurança e a saúde biopsicológica dos expostos a qualquer contexto jurídico-laborativo (MARANHÃO, 2016, p. 112). 
tiva não visa substituir os sistemas de justiça em vigor, mas tão somente oferecer uma nova abordagem para determinados tipos de conflitos (LARA, 2013, p. 70-71).

Outra lide que poderia ser objeto da justiça restaurativa é a reintegração do trabalhador com estabilidade provisória de emprego, como é, por exemplo, o caso dos trabalhadores membros da Comissão Interna de Prevenção de Acidentes (CIPA) (art. 10, II, "a" do Ato das Disposições Constitucionais Transitórias (ADCT)), da gestante (art. 10, Il, "b" do ADCT), do dirigente sindical (art. 543, § $3^{\circ}$, da Consolidação das Leis do Trabalho (CLT)), dos dirigentes de cooperativa (art. 55 da Lei $n .^{\circ} 5.764 / 1971$ ) e dos trabalhadores que sofreram acidente de trabalho (art. 118 da Lei n. $\left.{ }^{\circ} 8.213 / 1991\right)$ (LARA, 2013, p. 71-72).

Nesses casos, o juiz reintegra o trabalhador injustamente dispensado ou aplica a sanção prevista no artigo 496 da $\mathrm{CLT}^{28}$, podendo, na melhor das hipóteses, buscar a conciliação em audiência. Em qualquer caso, incorre-se na problemática de submeter uma pessoa a voltar ao trabalho em um ambiente hostil ou de aplicar sanção pecuniária que, contudo, não reposiciona o trabalhador no mercado (lícito) de trabalho, não lhe garantindo, consequentemente, uma renda futura (LARA, 2013, p. 71-72).

Com a aplicação da justiça restaurativa, é possível esclarecer a situação fática apresentada, facilitar a superação da questão emocional que impediria a volta do empregado e favorecer a continuidade da relação de emprego, um dos princípios basilares do direito do trabalho (LARA, 2013, p. 71-72).

Outro caso em que poderiam ser aplicadas as práticas restaurativas são as demandas provenientes de empresas familiares ou de empresas com número restrito de empregados ou mesmo de trabalho doméstico, situações em que a ligação emocional das pessoas no ambiente de trabalho tende a ser maior (LARA, 2013, p. 73).

Os casos envolvendo assédio moral no meio ambiente de trabalho também são aptos à aplicação das práticas restaurativas, podendo ser tratados no dia a dia do Ministério Público do Trabalho (MPT) por meio das notícias de fato de irregularidades que chegam ao órgão. 0 MPT, enquanto instituição burocrática apta a solucionar, administrar e transformar os CPIS, possui diversos mecanismos para tanto. Todavia, nenhum dos nomes de procedimentos ministeriais refere-se especificamente às práticas restaurativas. Portanto, não há uma categorização específica para elas, como há para os procedimentos administrativos de mediação (PA-MED) e de arbitragem (PA-ARB).

Contudo, isso não significa, necessariamente, que as práticas restaurativas não sejam adotadas em alguns procedimentos ministeriais, como será demonstrado pelo relato da aplicação das práticas restaurativas em 3 (três) procedimentos distintos que foram noticiados ao MPT-PA ${ }^{29}$.

O primeiro procedimento ministerial tratou de um caso de assédio moral em que as divergências entre a antiga e a nova gestão dificultavam a convivência no meio ambiente

28 Art. 496 da CLT - Quando a reintegração do empregado estável for desaconselhável, dado o grau de incompatibilidade resultante do dissídio, especialmente quando for o empregador pessoa física, o tribunal do trabalho poderá converter aquela obrigação em indenização devida nos termos do artigo seguinte.

29 Os procedimentos restaurativos aqui mencionados são narrativas genéricas com o intuito de ilustrar e de exemplificar a aplicação de tais práticas no âmbito do Ministério Público do Trabalho, pois, devido ao sigilo dos procedimentos restaurativos, não é permitida a divulgação de dados substanciais ou de dados que permitam a identificação dos casos restaurados ou em processo de restauração. 
de trabalho. Nesse caso, a antiga gestão sentia-se perseguida por diversas condutas da atual gestão, como, por exemplo, a exclusão de atividades de gerência, a exclusão da lista de aniversariantes do mês, a supressão de gratificação, a redução da verba salarial e outras. Diante desses fatos, o procurador em audiência sugeriu aos envolvidos a aplicação das práticas restaurativas para a restauração das relações interpessoais e profissionais dentro da instituição, sendo aceita por todos. Diante do consentimento, foi designada uma facilitadora devidamente credenciada com experiência na área. Optou-se pela metodologia dos círculos de construção de paz. Foram realizados os pré-círculos para compreender os sentimentos dos envolvidos e as necessidades não atendidas que culminaram naquela situação.

Em seguida, realizou-se o círculo de construção de paz, em que os sentimentos, as expectativas e as necessidades dos envolvidos foram esclarecidas. Os participantes comprometeram-se a praticar o respeito ao próximo, o auxílio mútuo, a paciência e o cuidado para com os colegas, bem como a fazer com que todos realizassem a escuta ativa focada nas atividades laborativas, no recepcionamento de dúvidas, elogios e críticas construtivas, buscando a empatia, o aperfeiçoamento profissional e a busca da saúde mental, física, social e espiritual de todos os colegas. 0 acordo foi assinado por todos e nele ficou registrada a responsabilidade daquela comunidade profissional. Esse procedimento está na fase do pós-círculo, em que há a averiguação se os compromissos assumidos estão sendo cumpridos.

O segundo procedimento ministerial ocorreu em outro caso de assédio moral, em que um grupo de trabalhadores sentia-se perseguido pela gestão devido a sua formação profissional. Segundo os trabalhadores, o tratamento diferenciado era expresso na fixação de carga horária que impedia o desempenho de outro trabalho, na exclusão de atividades inerentes à função e na desqualificação de seu desempenho profissional, o que lhes acarretou problemas psicológicos relacionados à autoestima.

Diante da recusa por um dos envolvidos do convite a participar das práticas restaurativas, o procurador do caso notificou, sob pena de condução coercitiva, os envolvidos a participar de um círculo de construção de paz, realizado por uma facilitadora designada. 0 procedimento restaurativo objetivou fazer com que os participantes se comprometessem a ser solidários com os colegas de trabalho, a cumprir as regras institucionais com igualdade, a ser profissionais com todos os colegas, a melhorar o acesso à comunicação com alguns colegas de trabalho e a respeitar os protocolos estabelecidos para determinados serviços. 0 acordo foi assinado por todos os participantes, tendo ficado registrada a responsabilidade daquela comunidade profissional. Esse procedimento também está na fase do pós-círculo.

O terceiro procedimento ministerial em que foram aplicadas as práticas restaurativas objetivou a restauração das relações entre os fundadores e os dirigentes de um projeto, cujos desentendimentos e discordâncias estavam inviabilizando a comunicação e, consequentemente, o bom andamento do projeto. No caso, todos os envolvidos consentiram na aplicação dos círculos de construção de paz, que foram realizados por uma facilitadora externa, tendo sido esclarecidos os mal-entendidos e tendo havido um diálogo franco sobre os desentendimentos passados, reconstruindo-se a comunicação para garantir o bom desempenho e desenvolvimento do projeto.

Observa-se que nenhum dos três procedimentos narrados possui uma categorização específica para demonstrar que nesses casos foi aplicada a justiça restaurativa, o que levou a prática ministerial a utilizar a justiça restaurativa como incidente em procedimentos de 
persecução de irregularidades trabalhistas. Dessa forma, a ausência de procedimento específico para designar a justiça restaurativa dificulta a quantificação dos casos em que as práticas restaurativas foram empregadas, bem como a avaliação da metodologia utilizada, se teve êxito ou fracassou.

Com a dificuldade enunciada, os membros e servidores do MPT, e o próprio CNMP, não conseguirão realizar uma pesquisa qualificada acerca da utilização das práticas restaurativas. Logo, sem essa pesquisa, a justiça restaurativa não será passível de elogios ou de críticas, que são muito importantes para o aprimoramento da restauração e de sua prática no âmbito ministerial. Portanto, seria interessante que o MPT criasse um procedimento específico para catalogar essa prática, que seria designado, por exemplo, pelo termo "procedimento ministerial restaurativo" (PMR) ou "procedimento ministerial de práticas restaurativas" (PMPR), ou por uma designação similar com a mesma finalidade.

A propósito, a sugestão feita estende-se a todos os Ministérios Públicos. De fato, avaliar os modos como as práticas restaurativas têm sido realizadas é de extrema importância para o desenvolvimento do instituto, sugerindo-se, inclusive, sua regulamentação pelo CNMP a fim de uniformizar, procedimentalizar e concretizar a justiça restaurativa no âmbito ministerial.

Observa-se, também, que os três casos relatados foram conduzidos por uma facilitadora externa à estrutura do MPT, que atuou de forma voluntária, isto é, sem quaisquer custos para a instituição. Esse detalhe é destacável, pois, para aplicar os procedimentos restaurativos, faz-se necessário um facilitador habilitado para tanto, ou seja, uma pessoa que tenha feito o curso de facilitador da justiça restaurativa.

O CNMP, tendo conhecimento dessa exigência, elucidou, no artigo 18 da Resolução n. ${ }^{\circ}$ 118/2014, que os membros e servidores do Ministério Público, inclusive o do Trabalho, serão capacitados pelas Escolas do Ministério Público, para que realizem sessões de negociação, conciliação, mediação e práticas restaurativas (CONSELHO NACIONAL DO MINISTÉRIO PÚBLICO, 2015, p. 8).

Entretanto, assevera-se que, dada a vivência dos membros e dos servidores do MPT, na qualidade de persecutores, não se mostram indicados para aplicar as práticas restaurativas diretamente, quando estão atuando em procedimentos ministeriais que não tenham por objeto específico a justiça restaurativa. Como dito, a vivência adquirida a partir do trabalho no órgão como persecutor mostra-se incompatível com a sua atuação enquanto facilitador nos procedimentos ministeriais de aplicação da justiça restaurativa, uma vez que o facilitador necessita ser o mais imparcial ${ }^{30}$, confiável e simétrico possível, para que a condução do círculo não gere um ambiente inseguro, em que, por certo, a justiça restaurativa pode vir a falhar, ou pior, a funcionar como mais um subterfúgio para conseguir apenas um acordo.

No procedimento do círculo de construção de paz, por exemplo, o facilitador ajuda o grupo a criar e a manter um espaço seguro para que todos os participantes possam falar honestamente e abertamente sem desrespeitar ninguém. 0 facilitador monitora o espaço e estimula as reflexões do grupo por meio de perguntas ou de tópicos sugeridos. Ele não pode direcionar o grupo para um determinado resultado previamente querido, pois sua função é 
iniciar um espaço respeitoso e seguro que envolva todos no compartilhamento da responsabilidade pelo espaço. Somado a isso, não é papel do facilitador consertar o problema que o círculo está reportando, apenas deve zelar pelo bem-estar de cada membro do círculo (PRANIS, 2010, p. 19).

Tal dificuldade já foi verificada nos procedimentos de mediação, tendo o artigo 113, $\S 5 .^{\circ}$, da Resolução n. ${ }^{\circ}$ 166/2019 do Conselho Superior do Ministério Público do Trabalho (CSMPT) ${ }^{31}$ determinado que, quando o procurador atuar como mediador, fica impedido, pelo prazo de um ano, de promover investigação ou adotar qualquer providência judicial em que estejam envolvidos quaisquer dos sujeitos envolvidos (CONSELHO SUPERIOR DO MINISTÉRIO PÚBLICO DO TRABALHO, 2019). Dessa forma, tal resolução reconhece que o mesmo procurador que aplica métodos de mediação (ou as práticas restaurativas) não pode atuar como persecutor, simplesmente judicializando a demanda em caso de insucesso.

Assim, sendo criado um procedimento específico que categorizasse a aplicação das práticas restaurativas, o procurador que atuar como facilitador ficaria igualmente impedido de atuar como persecutor ou demandante, devendo insistir nas práticas autocompositivas; não obtendo êxito, o procedimento deverá ser arquivado e encaminhada a notícia de fato para adoção de providências por outro membro do Ministério Público do Trabalho, de forma análoga ao previsto no artigo $113, \S 4 .^{\circ}$, da Resolução n. ${ }^{\circ} 166 / 2019$ do CSMPT ${ }^{32}$. Ademais, tal resolução também poderia ser modificada para contemplar tal impedimento dos procuradores que atuassem como facilitadores.

Vale ressaltar que o sigilo é de suma importância nas práticas restaurativas. 0 círculo, por exemplo, visa criar um espaço seguro entre os participantes que lhes permita abordar seus problemas sem medos de represálias. Consequentemente, caso não se adote o sigilo, a confiança será abalada, uma vez que, ainda que não intencionalmente, o procurador poderia utilizar informações obtidas por meio sigiloso - o círculo - para judicializar a demanda. Dito de outra forma, o facilitador precisa ser um agente imparcial, simétrico, disposto a compreender os problemas dos envolvidos e auxiliá-los a resolvê-los conjuntamente. Portanto, o facilitador precisa transmitir confiança aos participantes, o que não seria possível caso qualquer um dos envolvidos o enxergasse como alguém passível de prejudicá-lo com base nas informações obtidas de forma sigilosa.

Outra opção para o MPT é trabalhar com facilitadores credenciados (amigos ministeriais) que não estejam vinculados ao órgão, como ocorreu nos casos acima narrados. Essa opção implicaria a criação de um banco de dados de facilitadores credenciados. Quanto à atuação dos facilitadores, ela poderia ser pro bono ou pro labore. Esta última modalidade importaria em uma despesa a mais na dotação orçamentária do órgão, uma vez que muitos desses profissionais cobram para atuar como facilitadores ${ }^{33}$.

31 Art. 133 [...], § $5^{\circ} 0$ membro do Ministério Público do Trabalho que atuar como mediador fica impedido, pelo prazo de um ano, contado do término da última audiência em que atuou, a promover investigação ou adotar qualquer providência judicial em que estejam envolvidas quaisquer partes que integraram o procedimento de mediação ou conciliação.

32 Art. 133 [...], § $4^{\circ} \mathrm{Na}$ hipótese de constatação de ofensa aos direitos de que trata o inciso II que não possa ser solucionada no âmbito da própria mediação ou conciliação, o procedimento será arquivado e encaminhada notícia de fato para adoção de providências por outro membro do Ministério Público do Trabalho.

33 Observa-se que não está sendo emitido juízo de valores para ponderar se a cobrança para atuação enquanto facilitador é correta ou não, apenas se constata que um facilitador credenciado pode importar em um aumento dos gastos do MPT. 
Outra possibilidade é a criação de núcleos restaurativos com uma equipe multidisciplinar e a atuação conjunta de diversos órgãos trabalhistas, como a Justiça do Trabalho, o Ministério Público do Trabalho, as Delegacias Regionais do Trabalho e outros órgãos. Assim, os casos levados ao MPT seriam filtrados pelo próprio procurador que, verificando a possibilidade de aplicação da justiça restaurativa, instauraria um "procedimento ministerial restaurativo", encaminhando-o ao Núcleo e podendo, inclusive, atuar como facilitador, desde que respeitado o impedimento de atuação como persecutor ou demandista.

Ademais, tais núcleos também poderiam contar com o apoio das universidades públicas e privadas, que, engajadas na formação de profissionais de direito voltados para a autocomposição, ofertariam disciplinas optativas de capacitação de facilitadores, possibilitando, inclusive, o cumprimento do estágio obrigatório nesses núcleos. Assim, seria possível a atuação de facilitadores devidamente capacitados e voluntários, eliminando-se o gasto orçamentário.

Diante do exposto, constata-se que o Ministério Público, inclusive o do Trabalho, é um ator político-burocrático com poderes para instaurar procedimentos dialógicos para proceder à concretização de direitos sociais e à harmonização e à pacificação social, sendo as práticas restaurativas um desses procedimentos, uma vez que diversos casos que chegam à instituição versam sobre temáticas que possibilitam a aplicação da justiça restaurativa.

\section{CONSIDERAÇÓES FINAIS}

A história da justiça restaurativa remonta a algumas comunidades antigas, mas constata-se que o modelo atual baseia-se na tradição da Nova Zelândia. A justiça restaurativa busca uma aproximação das ações objetivando corrigir as necessidades humanas não atendidas, o dano causado, reconciliar as partes ligadas ao conflito, problema ou insatisfação social, criando um sentimento de responsabilidade e de compromisso em todos os envolvidos.

A justiça restaurativa tem como um de seus focos as necessidades da vítima, mas sem deixar de garantir que o(s) ofensor(es) assuma(m) sua(s) responsabilidade(s). Portanto, os pilares da justiça restaurativa são: as necessidades dos envolvidos, o dano cometido, as obrigações e responsabilidades e o engajamento de todos os afetados pelo ato lesivo. Elucidou-se que um dos objetivos da justiça restaurativa é tratar do ato lesivo (dano) e o outro é tratar as necessidades não atendidas e as causas que levaram à ofensa.

Apresentaram-se os três principais modelos de práticas restaurativas: os encontros vítima-ofensor, as conferências de grupos familiares e os processos circulares ou círculos de construção de paz, cada um implicando, em alguma medida, o diálogo entre interesses dos envolvidos, sempre de forma voluntária e cooperativa.

Após apresentar a justiça restaurativa, relatou-se a atuação do Ministério Público do Trabalho enquanto instituição com poderes para deliberar e discutir, em igualdade de condições, com os interessados e os envolvidos em conflitos, em problemas ou em insatisfações sociais, na busca da sua resolução, administração ou transformação. 
Constatou-se que o Ministério Público do Trabalho possui diversos procedimentos que possibilitam a sua atuação para concretizar direitos humanos sociais, políticas públicas e harmonizar e pacificar as relações sociais. Além disso, relatou-se que, no ano de 2015, no Ministério Público do Trabalho do Pará, Procuradoria Regional de Belém, foram instaurados 1.777 (mil, setecentos e setenta e sete) procedimentos, porém nenhum deles abordou como objetivo principal ou incidental a justiça restaurativa.

Em 2019, as práticas restaurativas foram aplicadas em três procedimentos distintos da Procuradoria Regional do Trabalho do MPT-PA, sediado em Belém (PA). Todavia, em nenhum desses procedimentos, o objeto principal foi o uso de práticas restaurativas, abordadas apenas incidentalmente.

Em seguida, analisou-se a Resolução n. ${ }^{\circ}$ 118/2014 do CNMP, que instituiu a Política Nacional de Incentivo à Autocomposição. Tal resolução motivou a mudança de perspectiva que ocorreu no Ministério Público, incluindo o do Trabalho, que passou a buscar em sua atuação a sedimentação da cultura da paz, a qual prioriza o diálogo e o acordo na resolução, administração e transformação dos conflitos, dos problemas e das insatisfações sociais.

Teceram-se ainda considerações e algumas críticas aos artigos 13, 14 e 18 da Resolução n. ${ }^{\circ} 118 / 2014$ do CNMP, que versam especificamente sobre as práticas restaurativas no âmbito ministerial.

Por fim, propôs-se a possibilidade de aplicação de práticas restaurativas às irregularidades trabalhistas de caráter coletivo que fossem noticiadas ao Ministério Público do TrabaIho, elucidando alguns casos que poderiam ensejar o uso dessas práticas, tais como os que envolvem o trabalho infantil, o trabalho escravo, os acidentes de trabalho, a reintegração do trabalhador com estabilidade provisória de emprego - por exemplo, os trabalhadores membros da CIPA (art. 10, II, "a" do ADCT), as gestantes (art. 10, II, "b" do ADCT), os dirigentes sindicais (art. 543, § $3 .^{\circ}$, da CLT), os dirigentes de cooperativa (art. 55 da Lei n. ${ }^{\circ} 5.764 / 1971$ ), os trabalhadores que sofreram acidente de trabalho (art. 118 da Lei n. ${ }^{\circ} 8.213 / 1991$ ), além dos casos de assédio moral no ambiente de trabalho.

Formularam-se algumas considerações e propostas acerca do uso da justiça restaurativa no Ministério Público do Trabalho, dentre as quais se destacam: a criação de um procedimento ministerial específico, "procedimento ministerial restaurativo" (PMR), para os casos em que fossem aplicadas as práticas restaurativas; a aplicação análoga do impedimento previsto no artigo $113, \S \S 4 .^{\circ}$ e $5 .^{\circ}$, da Resolução n. ${ }^{\circ}$ 166/2019 do CNMPT ao procedimento restaurativo, ou sua alteração para contemplar o impedimento das práticas restaurativas; a criação de um banco de dados com facilitadores cadastrados para a atuação nos casos.

Ademais, sugeriu-se também a criação de núcleos envolvendo todos os órgãos que lidam diretamente com irregularidades trabalhistas para a aplicação da justiça restaurativa, com a designação de procuradores para trabalhar como facilitadores, caso em que os procuradores ficam impedidos de atuar como persecutores ou demandistas por um determinado lapso temporal. Sugeriu-se ainda uma parceria com universidades públicas e privadas que permita o estágio voluntário nesses núcleos, oferecendo facilitadores devidamente qualificados, sem custos para o Ministério Público do Trabalho. A oferta de cursos de facilitador também deve ser incumbência das Escolas de Governo, como a Escola Superior do Ministério Público da União (ESMPU), nos termos do artigo 18 da Resolução n. ${ }^{\circ}$ 118/2014 do CNMP. 
Por fim, conclui-se que o Ministério Público do Trabalho é um ator político-burocrático com poderes constitucionais e infraconstitucionais para instaurar procedimentos dialógicos para proceder à concretização dos direitos sociais, bem como para promover a harmonização e a pacificação social, sendo as práticas restaurativas um desses procedimentos de forma principal ou incidental, uma vez que diversos casos que chegam à instituição versam sobre temáticas que possibilitam a aplicação da justiça restaurativa, além de reunirem os elementos necessários a sua aplicação.

\section{REFERÊNCIAS}

ACKERMAN, Bruce. The new separation of powers. Harvard Law Review, Cambridge, Mass., v. 113, n. 3, p. 633725, Jan. 2000.

ARAÚJO, Mayara de Carvalho. Justiça restaurativa comunitária: análise de efetividade a partir do Programa Conjunto da ONU em Contagem - MG. 2019. Tese (Doutorado em Direito) - Faculdade de Direito, Universidade Federal de Minas Gerais, Belo Horizonte, 2019.

BARROS, Ana Maria Soares R. de. Justiça restaurativa: uma justiça do trabalho mais cidadã. Trabalho apresentado no XIII Congresso Nacional de Magistrados da Justiça do Trabalho, Maceió, 2006.

CONSELHO NACIONAL DE JUSTIÇA. Mapeamento dos Programas de Justiça Restaurativa. Seminário Justiça Restaurativa. Conselho Nacional de Justiça: Brasília, 2019.

CONSELHO NACIONAL DO MINISTÉRIO PÚBLICO. Resolução n. ${ }^{\circ} 118$, de $1 .^{\circ}$ de dezembro de 2014. Dispõe sobre a Política Nacional de Incentivo à Autocomposição no âmbito do Ministério Público e dá outras providências. Diário Oficial da União, Brasília, DF, 27 jan. 2015. Seção 1.

CONSELHO SUPERIOR DO MINISTÉRIO PÚBLICO DO TRABALHO. Resolução n. ${ }^{\circ}$ 166, de 10 de maio de 2019. Dispõe sobre a atuação finalística no âmbito do Ministério Público do Trabalho. Diário Oficial da União, Brasília, DF, 25 jun. 2019. Seção 1, p. 48.

CORDIOLI, Leandro. Redescobrindo a equidade na gramática dos direitos: horizontes para uma teoria da justiça personalista e ética na retórica do Direito. In: SEMANA ACADÊMICA DO PROGRAMA DE PÓS-GRADUAÇÃO EM FILOSOFIA DA PUCRS. Porto Alegre: Editora Fi, 2015. v. 2, p. 185-209.

DOYAL, Len; GOUGH, Ian. Teoría de las necesidades humanas. Barcelona: Icaria, 1994.

JACCOUD, Mylène. Princípios, tendências e procedimentos que cercam a justiça restaurativa. In: SLAKMON, Catherine; VITTO, Renato Campos Pinto de; PINTO, Renato Sócrates Gomes (Org.). Justiça restaurativa. Brasília, DF: Ministério da Justiça e Programa das Nações Unidas para o Desenvolvimento, 2005. p. 163-188.

LARA, Caio Augusto Souza. A justiça restaurativa como via de acesso à justiça. 2013. $101 \mathrm{f}$. Dissertação (Mestrado em Direito) - Faculdade de Direito, Universidade Federal de Minas Gerais, Belo Horizonte, 2013.

LEDERACH, John Paul. Transformação de conflitos. Tradução de Tônia Van Acker. São Paulo: Palas Athena, 2012.

MACÊDO, Marcus Paulo Queiroz. O Ministério Público e as novas técnicas de atuação na defesa dos direitos fundamentais. In: ALMEIDA, Gregório Assagra de; SOARES JUNIOR, Jarbas (Coord.). Teoria geral do Ministério Público. Belo Horizonte: Del Rey, 2013. p. 335-374.

MARANHÃO, Ney. Meio ambiente do trabalho: descrição jurídico-conceitual. Revista Direitos, Trabalho e Política Social, Cuiabá, v. 2, n. 3, p. 80-117, jul./dez. 2016.

MIRANDA, Marcos Paulo de Souza. A recomendação ministerial como instrumento extrajudicial de solução de conflitos ambientais. In: CHAVES, Cristiano; ALVES, Leonardo Barreto Moreira; ROSENVALD, Nelson (Coord.). Temas atuais do Ministério Público: a atuação do Parquet nos 20 anos de Constituição Federal. Rio de Janeiro: Lumen Juris, 2010. p. 365-405. 
ORSINI, Adriana Goulart de Sena; LARA, Caio Augusto Souza. A justiça restaurativa: uma abrangente forma de tratamento de conflitos. Biblioteca Digital do TRT-MG. 2013. Disponível em: http://as1.trt3.jus.br/bd-trt3/handle/11103/2665. Acesso: 6 maio 2020.

PAZ, Silvana Sandra; PAZ, Silvina Marcela. Justiça restaurativa: processos possíveis. In: SLAKMON, Catherine; VITTO, Renato Campos Pinto de; PINTO, Renato Sócrates Gomes (Org.). Justiça restaurativa. Brasília, DF: Ministério da Justiça e Programa das Nações Unidas para o Desenvolvimento, 2005. p. 125-130.

PINTO, Renato Sócrates Gomes. Justiça restaurativa é possível no Brasil. In: SLAKMON, Catherine; VITTO, Renato Campos Pinto de; PINTO, Renato Sócrates Gomes (Org.). Justiça restaurativa. Brasília, DF: Ministério da Justiça e Programa das Nações Unidas para o Desenvolvimento, 2005. p. 19-39.

PRANIS, Kay. Círculos de justiça restaurativa e de construção de paz: guia do facilitador. Tradução de Fátima de Bastiani. [s.I.]: Escola Superior de Magistratura da Associação dos Juízes do Rio Grande do Sul, 2010.

SILVA, Sandoval Alves da. Ensaio ao estudo da imparcialidade do Ministério Público. Revista Jus Navigandi, Teresina, ano 14, n. 2124, 25 abr. 2009. Disponível em: https://jus.com.br/artigos/12699. Acesso em: 6 maio 2020.

SILVA, Sandoval Alves da. O Ministério Público e a concretização dos direitos humanos. Salvador: Juspodivm, 2016.

SILVA, Sandoval Alves da. O (in)acesso à justiça social com a demolidora reforma trabalhista. In: MIESSA, Élisson; CORREIA, Henrique (Org.). A reforma trabalhista e seus impactos. Salvador: Juspodivm, 2017. v. 1, p. 1075-1103.

SILVA, Sandoval Alves da. A sociedade e a solução de conflitos negociados. 2019. No prelo.

SILVA, Sandoval Alves da; SIQUEIRA, João Renato Rodrigues. Acesso à justiça no Projeto "Escrevendo e Reescrevendo a Nossa História" (Pernoh). 2020. No prelo.

SOUZA NETO, Cláudio Pereira de. O dilema constitucional contemporâneo entre neoconstitucionalismo econômico e constitucionalismo democrático. In: COUTINHO, Jacinto Nelson de Miranda; LIMA, Martonio Mont'Alverne Barreto (Org.). Diálogos constitucionais: direito, neoliberalismo e desenvolvimento em países periféricos. Rio de Janeiro: Renovar, 2008. p. 119-132.

TARTUCE, Fernanda. Mediação nos conflitos civis. 4. ed., rev., atual. e ampl. Rio de Janeiro: Forense; São Paulo: Método, 2015.

TORRES CARRILLO, Alfonso. El retorno a la comunidad: problemas, debates y desafíos de vivir juntos. Bogotá: El Búho, 2013.

ZEHR, Howard. Justiça restaurativa. Tradução de Tônia Van Acker. Ed. ampl. e atual. São Paulo: Palas Athena, 2015.

ZEHR, Howard. Trocando as lentes: um novo foco sobre o crime e a justiça. Tradução de Tônia Van Acker. São Paulo: Palas Athena, 2008.

Recebido/Received: 20.05.2020.

Aprovado/Approved: 27.06.2020. 